IZA DP No. 10069

Help Not Wanted: The Dismal Science of Youth Unemployment's Scarring Effect

Jordan Glatt

Phanindra V. Wunnava

July 2016 


\title{
Help Not Wanted: The Dismal Science of Youth Unemployment's Scarring Effect
}

\author{
Jordan Glatt \\ Deloitte Consulting
Phanindra V. Wunnava
Middlebury College
and IZA

Discussion Paper No. 10069

July 2016

IZA
P.O. Box 7240
53072 Bonn
Germany

Phone: +49-228-3894-0

Fax: +49-228-3894-180

E-mail: iza@iza.org

\begin{abstract}
Any opinions expressed here are those of the author(s) and not those of IZA. Research published in this series may include views on policy, but the institute itself takes no institutional policy positions. The IZA research network is committed to the IZA Guiding Principles of Research Integrity.

The Institute for the Study of Labor (IZA) in Bonn is a local and virtual international research center and a place of communication between science, politics and business. IZA is an independent nonprofit organization supported by Deutsche Post Foundation. The center is associated with the University of Bonn and offers a stimulating research environment through its international network, workshops and conferences, data service, project support, research visits and doctoral program. IZA engages in (i) original and internationally competitive research in all fields of labor economics, (ii) development of policy concepts, and (iii) dissemination of research results and concepts to the interested public.
\end{abstract}

IZA Discussion Papers often represent preliminary work and are circulated to encourage discussion. Citation of such a paper should account for its provisional character. A revised version may be available directly from the author. 


\section{ABSTRACT \\ Help Not Wanted: The Dismal Science of Youth Unemployment's Scarring Effect ${ }^{\star}$}

The scarring effect is defined as an increase in the probability of future unemployment spells and the reduction of subsequent wages as the result of joblessness early in one's working years. Many youths get into a rut at the beginning of their professional careers when they become unemployed, hindering future individual prospects and producing negative consequences for the economy as a whole. Because there is considerable evidence in the United States that early job displacement is followed by a higher risk of subsequent unemployment and lower trajectory for future earnings after re-entry, it is crucial to gain a better understanding of the economic factors that influence the youth unemployment rate in order to reduce the consequences on youths' future outlooks (Arulampalam, Gregg, and Gregory, 2001). This study not only demonstrates that the scarring effect is real but also allows for policy recommendations to be obtained from this analysis.

JEL Classification: J24, J31, J64, I21

Keywords: scarring, youth unemployment, unemployment spells, job displacement, earnings, re-entry, Great Recession

Corresponding author:

Phanindra V. Wunnava

David K. Smith '42 Chair in Applied Economics

Department of Economics

Middlebury College

Warner Hall 502F

Middlebury, VT 05753

USA

E-mail:wunnava@middlebury.edu

\footnotetext{
* An earlier draft of this paper was presented at the 2016 WEAI Conference CEP session titled: Issues in Labor Economics (Portland, OR) on July $2^{\text {nd }}, 2016$. We would like to thank Terry Simpkins and Sanjay Wunnava for their constructive editorial suggestions.
} 


\section{"Help Not Wanted: The Dismal Science of Youth Unemployment’s Scarring Effect”}

\section{INTRODUCTION}

Resolving the issue of high unemployment rates has been a high priority for many politicians in recent years, given the negative labor market consequences that were brought about during the Great Recession. However, when one is presented with the unemployment rate or any information related to its potential causes or solutions, the general tendency is to think of this measure as it relates to adults, without much consideration of the youth population (Demidova and Signorelli, 2012). This is worrisome because youths tend to face higher rates of unemployment than their adult counterparts and suffer from alarming consequences older workers do not experience such as the scarring effect (Bell and Blanchflower, 2009). Scarring occurs when unemployment at the beginning of one's professional career leads to lower future wages and deterioration of his or her later employment opportunities (Gomez-Salvador and Leiner-Killinger, 2008). This is therefore likely to lead to a cycle where spells of unemployment alternate with low-paid and unstable jobs as well as underemployment. If the government is concerned with the long-term welfare and development of this nation, it should take strides towards finding better ways to integrate young people into labor market positions.

The issue of youth unemployment is important to study because of its impacts on individual youths, society, and the health of the economy as a whole. Therefore, a more in-depth exploration of the factors contributing to youth unemployment was conducted in order to reach conclusions leading to more useful policies that might mitigate some of these concerns. Even though the government currently has several programs in place that attempt to lower the incidence of high youth unemployment, the benefits of these initiatives have room for improvement. Thus, in order to contain this issue and provide youths with a greater number of opportunities for professional success at the beginning of their careers, the first step is to identify how certain economic factors influence youth unemployment.

This study is divided into two parts in order to explore this topic in greater detail. The first section provides a description of the causes and consequences of both youth unemployment and the scarring effect, a comparison to adult unemployment, an identification of historic structural changes in the American labor market, an exploration of the role of economic conditions, as well as an examination of other related topics. The second section presents methodology and the econometric analysis with an estimation of the effects several economic factors have on American youth unemployment and earnings. Using quarterly data from 1980-2013, this relevant and somewhat overshadowed issue can be addressed more successfully through changes in outlook and policy. In order to accomplish this objective, the model incorporates the economic factors utilized most frequently in the literature while correcting for econometric issues.

Several other questions will also be answered throughout the study: Does the scarring effect exist, and if so, to what extent does it affect future outcomes? Whom does it affect most severely? How do economic conditions affect youth joblessness? What effect(s) does changing the minimum wage have on 
youth unemployment? What role does spending on job training play in the employment prospects of youths? What is the relationship between the youth and adult unemployment rates? How do all of these factors interact to affect the youth unemployment rate?

\section{INSIGHTS FROM THE LITERATURE}

This section gives an overview of the multiple facets of the previous literature focusing on youth unemployment relevant to the research objectives of this study.

A. Defining Youth Unemployment: Before proceeding, it is important to define what is meant by the term youth unemployment. Specifically, this term can be divided into two parts, youth and unemployment. Due to societal, institutional, and cultural factors, there has been some disagreement over how to define the term "youth," especially across different countries. But in general, the age group associated with young people is linked to the role they play in society (Choudhry, Marelli, and Signorelli, 2012). For the sake of this study, data will be used from Americans ages 16 to 24, as this is most commonly used as the age range for youths by data sources within the United States.

Another controversial term to define is "unemployment," because this value depends greatly on the parameters that are set for its scope. Headline (U3) unemployment consists of people who have not worked for more than one hour during the last month but are actively seeking employment, whereas U6 unemployment includes those captured by U3 as well as discouraged, marginally attached, and part-time workers. Therefore, depending on how the unemployment rate is measured, slightly different results will appear because while U3 presents a much more focused measure of the unemployment rate, U6 is more broad and includes more categories of people. However, because U3 unemployment is more commonly used in economic studies and by the media, the current study will use this measure in order to remain consistent with what has been employed in the past. Nevertheless, it is important to make the distinction between U3 and U6 because of the somewhat different results they produce due to their different calculation methods.

Unemployment can also be frictional, structural, or cyclical in nature, all of which are believed to contribute to the unemployment of youths. Frictional unemployment is especially relevant to youths because it encompasses unemployment resulting from job searches, either for a new position or for one's first position; however, some level of frictional unemployment is actually desirable because this type of unemployment allows people in the labor force to find jobs that best match their qualifications. Similarly, for youths, structural unemployment reflects a mismatch between what firms are seeking in their employees and the skills of those in the labor force. In other words, labor supply exceeds labor demand with structural unemployment, and this is particularly applicable to youths because their lack of skills and experience oftentimes make them appear less desirable to employers. Finally, there is cyclical unemployment, which is joblessness resulting from changes in the business cycle. This also has a large impact on the youth population because of their large degree of sensitivity to economic downturns. As a result, all three types of 
unemployment are included in the measure of the youth unemployment rate because they all contribute to this value.

It is also important to distinguish between being unemployed (out of work and looking for a job) and being out of the labor force (out of work and not looking for a job) since the difference is less clear for youths than for adults. This is because many young people are on the border between looking for work and not looking for work, and frequently switch between the two. Other factors to consider are that some young people may want to work but have simply given up looking, may not be seeking work as actively as unemployed adults, or may also be enrolled in school full time (Freeman and Wise, 1982). Based on all these issues, it is apparent that even though the difference between being unemployed and out of the labor force is somewhat unclear for adults, there is even more ambiguity for youths. Therefore, the youth unemployment rate may not completely capture the full story, but it is the best proxy to measure the degree of youth joblessness that is present within the economy.

B. Causes of Youth Unemployment: Youth unemployment can arise for a variety of reasons, such as youths having a lack of work-relevant skills, information and connections for acquiring skills, experience and credentials, and opportunities for entry-level work that is career oriented. Unfortunately, this lack of skills, experience, and opportunities often leads to the experience trap. Because employers select workers with experience, many new labor market entrants are not hired and therefore cannot increase the experience that is sought after by employers. This creates a vicious cycle. On the other hand, those youths who have actually obtained employment have a higher likelihood of being laid off than employed adults because of the lower associated costs of contract termination of younger employees due to their limited experience and job tenure. Regardless of a youth's employment standing in the labor market (i.e, employed or unemployed), he or she is vulnerable to unemployment spells because of the high level of skill and experience standards expected of employable workers. This can be explained by the mismatch between supply and demand for youth labor as well as between employer requirements and youth experiences and skills. There is typically a demand for youth labor in unskilled or low-level positions; however, when looking at the economy as a whole, there are not many of these positions to begin with let alone available. Additionally, because young people typically enter the labor force with few relevant skills and low levels of experience, they are generally not the most desirable new hires in upper-level positions that typically require more credentials. These two reasons contribute greatly to the surplus of youth workers.

Youth unemployment may also exist because people typically search for an adequate job match upon entry into the labor market (Cockx and Picchio, 2013). Because one's first employment positions are likely to provide him or her with the necessary skills and experience going forward with employment in similar positions, it is important to find a good match at the beginning of one's professional career. This often leads to a longer job search process in order to identify and acquire a satisfactory and fulfilling position. However, due to the longer waiting time between entry into the labor market and one's first position, high levels of 
youth unemployment during the search process are likely to result. This tends to lead to negative outcomes both at the time and going forward - Youths may become discouraged and drop out of the labor force or take lower paying jobs without exploring other possibilities (Hills, 1990).

Youths also tend to be particularly prone to labor market inefficiencies, which lead to excessively low employment opportunities. This may be the case because youths are more likely than adults to be disenfranchised in wage negotiations, unprotected by labor turnover costs, have little influence on union objectives, and have productivity levels that are misunderstood by employers (Orszag and Snower, 1999). However, policy makers are divided over the appropriate response. Some believe that high unemployment rates are the efficient outcome of the free market. Without a long-term commitment to one position, young workers are provided with more time to explore other opportunities and clarify their job preferences. Thus, some claim that moving in and out of employment is actually beneficial early on in one's career. In addition, it takes time for youths to determine the areas in which their skills thrive, so they may experience unemployment in the hope of finding newer positions that better match their skills. But young people often get locked into spells of long-term unemployment, and for those youths who do not find jobs reasonably promptly upon entry into the labor market, it becomes progressively more difficult to gain employment as time passes. This is because they are unable to improve their skills through on-the-job training and/or become discouraged and stigmatized in the labor market (Orszag et al., 1999).

C. Youth vs. Adult Unemployment: There are many similarities between fluctuations in the youth and adult unemployment rates because general business conditions affect all groups within the population. However, it is believed that youth unemployment follows a different trajectory than adult unemployment and trends toward poorer outcomes. While youth unemployment worsens during economic downturns, it persists during prosperous economic times (Bell et al., 2009). The youth unemployment rate is especially sensitive to economic downturns because, when faced with a recession, firms typically freeze hiring and lay off workers, both of which tend to affect youths disproportionately. This commonly results from youths having less specific human capital relevant to the particular firm and also fewer general work skills. Additionally, because young people typically do not have as much experience with job-hunting, they are likely to have more trouble finding and obtaining a secure working position. Finally, young people tend to lack the financial independence and autonomy that adults have. Because they are usually linked financially to their families, many unemployed youths suffer from a decreased incentive to move where there are more prosperous job opportunities, thus severely limiting potential job prospects (Bruno and Cazes, 1998). Overall, given these large obstacles, the literature has shown that it is difficult for youths to achieve a rapid and direct entry into the labor market, further contributing to the issue of youth unemployment and illustrating differences between youths and adults.

D. Scarring Effect: Even though unemployment, regardless of when it occurs, can be damaging to one's future prospects, it is suggested that joblessness is particularly harmful during the early years of 
employment eligibility due to the scarring effect. This is because youth unemployment not only brings about the obvious loss of current income during the unemployment spell, but it also inflicts a longer-term "scar" through an increased likelihood of being unemployed in the future and receiving lower earnings in subsequent employment. In fact, studies estimate that this wage scar results in a 10 to 15 percent decrease in future wages (Bell et al., 2009). Unemployment early in one's life is therefore likely to have negative consequences for one's later career pursuits due to the impairment of productive potential as well as a decline in employment and earnings opportunities.

E. Causes of the Scarring Effect: There are many reasons why the scarring effect is believed to exist as a result of youth unemployment. For instance, patterns of behavior tend to persist. If lazy habits are developed during an unemployment spell, it is likely that this type of behavior will continue afterwards and cause these people to be less productive when actually participating in the work force. Next, skills are also likely to depreciate during unemployment because they may become obsolete from lack of use or because advancements lessen the value of formerly acquired capabilities, a phenomenon known as atrophy. In fact, human capital theory suggests that unemployment brings about the deterioration of general skills in addition to precluding the accumulation of work experiences. Future earnings and employment are therefore likely to be lower than if unemployment had not occurred. On the other hand, because young workers enter the labor market as inexperienced and gain skills by working on the job, unemployed youths tend to fall further and further behind their peers who have jobs because these unemployed youths are unable to make up for the lack of new skill accumulation that occurs during their unemployment spell. Early career outcomes are crucial to a worker's maintenance and development of skills, and unemployed youths are missing out on these key growth opportunities. Finally, employers may perceive unemployment as a signaling device, suggesting that the person is less productive. Because productivity is imperfectly observable, an employer may offer a lower wage as a result of a past history of unemployment. In sum, young people who are unemployed tend to become more vulnerable and unable to improve their skills, resulting in worse employment and earnings outlooks later on in their careers (Görlich, Stepanok, and Al-Hussami, 2013). Therefore, the scarring effect that arises from youth unemployment should be of top concern because of the damaging consequences early unemployment has on future career pursuits.

F. Consequences of Youth Unemployment for Individual Youths: A youth who is unemployed for six months is expected to earn about $\$ 22,000$ less over the next ten years than they could have earned if they had not been unemployed (Ayres, 2013). In addition to this direct cost, there are also several other negative consequences of unemployment for the individual, such as behavioral and psychological effects like an increased likelihood of involvement in criminal activities, dependence on family, domestic violence, poor social adaptation, and psychological issues (e.g., depression, loss of confidence, and low self-esteem) (Kabaklarli, Er, and Bulus, 2011). Many of these trends stem from a deterioration of an individual's wellbeing due to worsened expectations of becoming unemployed in the future. Thus, past unemployment is 
likely to inflict damage on the human psyche that leads to lower life satisfaction and professional motivation going forward (Knabe and Ratzel, 2011). Other negative consequences include postponement of marriage and deceleration of procreation because of the limited ability to begin and support a family if these youths are unemployed (Accornero, 1989). Therefore, while unemployment does generate a loss of income, there are many other consequences that go well beyond this direct cost to the individual.

G. Economic Consequences of Youth Unemployment: While young people experience economic consequences as a result of early unemployment, this issue is also worrisome for the economy as a whole. In fact, it is estimated that youth joblessness that occurred solely during the Great Recession will result in a total of $\$ 21.4$ billion in lost earnings over the next decade (Ayres, 2013). This is primarily because unemployed youths translates to unutilized labor potential and less labor input from those who are supposed to improve production processes with their supposedly more up-to-date and innovative expertise. The energy, skills, and aspirations of young people are assets that the society cannot afford to waste because of their importance to the economic health of the nation. Additionally, the economic costs of youth unemployment are especially large because young people's marginal propensity to consume is higher than that for adults. Thus, a higher youth unemployment rate would, in theory, lead to decreased consumption and therefore GDP. Youth unemployment also places a large burden on the government because of a reduced tax base as well as increased social welfare costs, such as unemployment benefits and other government assistance programs. In fact, it is estimated that the fiscal cost of the 6.7 million American youths who are currently unemployed will be $\$ 1.6$ trillion (Ayres, 2013). Therefore, it is apparent that several macroeconomic consequences result from high levels of youth unemployment, suggesting that it is not just youths who feel the consequences of their unemployment.

H. Structural Changes in the Labor Market: Over the course of American history, the labor market has undergone many fluctuating trends, which have contributed to the changes in youths' employment and wage outcomes. For example, in recent decades, there have been outward shifts of both the labor supply and demand curves for skilled workers, therefore leading to an increase in both the equilibrium price and quantity of skilled workers. On the other hand, the labor supply for unskilled workers has remained roughly constant while the labor demand has shifted inward (Blanchflower, 2000). Hence, in contrast to the outcome in the labor market for skilled workers, the equilibrium for unskilled laborers is now characterized by a lower price and quantity, which most affects the youth population.

Additionally, the composition of unemployed people has switched from being primarily made up of male adult heads of the household who needed jobs to support their families to young single men and women who are striving to begin their careers and construct a financial foundation on which to establish the rest of their lives (Filges and Larsen, 2004). There are many factors that have brought about this change; those who were traditionally out of the labor force are now seeking out jobs, more young people are having difficulty finding their first real jobs, and there are more women (both young and adult) searching for and finding jobs. 
Another structural change that has occurred in recent years is that unemployment is brought about more frequently due to jobs not found than to jobs lost, which speaks to the youth experience. In fact, the number of youths searching for their first job is increasing at a steady pace, and there are currently more people without a real work experience or position than ever before. Classic unemployment was generally composed of those who temporarily lost their jobs, but contemporary unemployment might become a more long-term, structural problem because of the struggle to find first jobs (Filges et al., 2004). Also, young people are tending to enter the labor market much later than in previous years. This can be explained by the common protraction of schooling due to social and economic benefits of education, the struggle to find jobs, and the desire to choose a job rather than being forced into one.

When making hiring decisions, firms take many factors into consideration, such as previous work experiences and educational background. However, it appears as though past experience tends to outweigh education in the eyes of employers. Because firms have started to value experience over education, beginning employment directly out of school has become increasingly unusual (Bruno et al., 1998). In order to fill the time when unemployed, many youths have decided to go back to school and improve their qualifications. This extension of education has led to an increase in the supply of educated young people, but it has also been suggested that there is a mismatch between the educational system and the real needs of the economy, raising the issue of the importance of education when it comes to employment. In fact, as more and more youths are postponing work and continuing their education instead, the proportion of educated young people who are having trouble entering the labor market has also increased (Bruno et al., 1998).

I. Minimum Wage and Youth Unemployment: As part of the Fair Labor Standards Act of 1938, a national minimum wage was established in the United States and has since become a politically contentious issue. Much of the debate has surrounded the potential effects of an increase in the wage floor on employment levels (Neumark and Wascher, 2004). Even though employers are required by law to pay workers at least a certain wage, this higher-than-equilibrium rate theoretically leads to increased unemployment; however, recent studies have produced many conflicting results. One reason for this is that the effects of the minimum wage may differ across segments of the population (Neumark et al., 2004). The minimum wage has been of particular concern in terms of youth unemployment because younger workers are less experienced and productive than older workers and are therefore more likely to receive the minimum wage. In other words, the effects of a minimum wage tend to be large at the beginning of one's professional career, but these effects decrease over time as he or she acquires more experience. The presence of a minimum wage also prevents youths from accepting lower wage matches that would have allowed them to gain employment and skills in the labor market. Additionally, in relation to the scarring effect, exposure to minimum wages at a young age has been shown to contribute to these people working and earning less later in life because minimum wage jobs tend to offer little in the way of promotion or advancement due to limited 
skill development and motivation to progress (Gorry, 2013). In summary, increases in the minimum wage tend to increase the vulnerability to unemployment and its consequences for younger workers.

J. Economic Conditions and Youth Unemployment: Even though the youth and adult unemployment rates move in a parallel fashion, youths tend to be more cyclically sensitive than adults and suffer disproportionately. This makes sense because youths often have a more precarious position in the labor market due to their lesser skills and experience (Gorry, 2013). Youths are more likely to experience unemployment during economic downturns because they are the easiest to remove from employed positions and firms are also more hesitant to hire new and inexperienced workers, especially in this economic state, which comes at the greatest cost to the young.

The issue of youth unemployment has been particularly relevant recently given the impact of the Great Recession on American job prospects. Even though growth has picked up in the United States in recent years, high levels of youth unemployment have persisted (Ayres, 2013). In fact, the level and duration of youth unemployment has been on the rise since 2008. This includes the number of young people who are not in employment, education, or training. This has unfortunately led to concerns about a "lost generation" as well as the increasing costs of managing the economic and social consequences of the inactivity of unemployed youth (Maguire, 2013). Today's youths face the worst employment prospects in recent American history, and trends in youth unemployment since the 1980s have suggested that the labor market is becoming even harsher towards young workers. Therefore, even before the Great Recession, young people had difficulty in the labor market, and their employment situation has only worsened since this most recent economic downturn. Additionally, over the past couple decades, employment and labor force participation have declined for this age group, whereas the unemployment rate has risen. In comparison, however, these measures have remained relatively stable or even increased for older workers, thus suggesting that the poor health of the economy was a large contributor to high youth unemployment. In fact, since the 1980s, the employment-to-population ratio for youth has fallen, with the greatest decreases within the past decade.

However, the youth unemployment situation has differed in other countries, especially those in Europe because of their friendlier labor markets, where youth unemployment rates during the Great Recession were already low and in comparison to the adult unemployment rates. One reason for these different outcomes is Europe's focus on strong workforce-development systems that support apprenticeships, vocational programs, and other training programs, which greatly improves the youth situation by addressing their main weaknesses in the job market (Ayres, 2013). As demonstrated through the relative success of European countries in containing the issue of youth unemployment, it is apparent that the United States could improve its situation through similar action.

Given youth unemployment's rising relevance, it is important to generate more up-to-date and comprehensive models in order to produce more reliable and successful policy changes targeting this issue. Even though some of the causes of youth unemployment have already been explored in isolation by other 
studies, the research is lacking in providing models that capture the working parts all throughout the economy. Therefore, rather than just focusing on how economic health or the minimum wage affect the youth unemployment rate on their own, the current study looks at many of these influences simultaneously in order to provide policymakers with a more complete picture of the factors contributing to changes in the youth unemployment rate.

\section{METHODOLOGY}

In order to learn more about the determinants of American youth unemployment and to identify the existence of the scarring effect, previous literature was searched to pinpoint the most successful modeling structures employed in the past as well as to determine gaps in the research to be further clarified. Because the scarring effect is broken into two parts (i.e., effects on future unemployment and earnings), the current study utilizes two models in order to pick up on both aspects of this economic phenomenon. As a result, the first model uses the youth unemployment rate as the dependent variable, while the second model has real median weekly youth earnings on the left-hand side. Both models contain the lagged youth unemployment rate as an independent variable, whose estimated coefficient provides better insight into quantifying the scarring effect. Whereas Model 1 uses the first lagged term of the youth unemployment rate, Model 2 uses the fourth lagged term due to further delayed effects on the earnings side. By using these two models, the current study is able to examine the different components of the scarring effect and reconcile the results.

A. Model 1 - Using YUR $\mathbf{Y}_{t}$ as the Dependent Variable: The following is the structure used for Model 1, which was constructed using the most prominent variables found in the literature. From an estimation of this model, one can identify the extent to which different economic factors contribute to youth unemployment and make policy recommendations where necessary. Additionally, through the incorporation of the lagged youth unemployment rate on the right hand side, more information can be gleaned about the scarring effect's relationship with this factor. ${ }^{1}$

$$
(+) \quad(+) \quad(-) \quad(+) \quad(+) \quad(-)
$$

$$
Y U R_{\mathrm{t}}=\beta_{0}+\beta_{1} Y U R_{t-1}+\beta_{2} A D U L T_{\mathrm{t}}+\beta_{3} \operatorname{lnGDP_{t}}+\beta_{4} M W_{\mathrm{t}}+\beta_{5} I N F L A_{\mathrm{t}-1}+\beta_{6} T R A I N_{\mathrm{t}}+\varepsilon_{\mathrm{t}}
$$

YUR: $\quad$ youth unemployment rate ${ }^{2}$

ADULT $_{\mathrm{t}}$ : adult unemployment rate

GDP $_{\mathrm{t}}: \quad$ real GDP per capita

$\mathrm{MW}_{\mathrm{t}}$ : $\quad$ real Federal minimum wage

INFLA $_{\mathrm{t}-1}: \quad$ inflation lagged by a quarter

TRAIN $_{\mathrm{t}}$ : $\quad$ real spending of Employment and Training Administration (ETA) (millions)

\footnotetext{
${ }^{1}$ Each of the variables measured in real dollars have been deflated using the CPI in base years 1982-1984. By converting nominal into real data, this allows for more reliability of and consistency between variables.

${ }^{2} \mathrm{YUR}_{\mathrm{t}}$ and $\mathrm{YUR}_{\mathrm{t}-1}$ take on different values depending on the specific gender/race model. For example, in the male submodel, $\mathrm{YUR}_{\mathrm{t}}$ is the male youth unemployment rate and $\mathrm{YUR}_{\mathrm{t}-1}$ is lagged male youth unemployment rate and so on.
} 
While most of the previous studies tended to focus on the effects of one specific aspect of the economy, such as economic downturns or changes in the minimum wage, it was also important to look at the economy as a whole because these changes rarely happen in isolation. Since most studies have been indecisive in their results, the goal of this more comprehensive analysis of the youth unemployment rate was to lead to more conclusive outcomes and policy implications.

The main factors that appear throughout the literature as explanations for the presence of youth unemployment generally tend to fall under the categories of economic circumstances, labor market conditions and policies, and education and skill levels. The strength of the economy is a noteworthy determinant of youth unemployment, as there appears to be a countercyclical relationship in theory (Kabaklarli et al., 2011). In fact, young people tend to be among those most severely influenced by economic dynamics. Given that the labor market is highly affected by the stability of the economy, it is crucial to determine the estimated relationship between the health of the economy and youth unemployment. Another labor market factor is the federal minimum wage, which relates directly to government policy (Bruno et al., 1998). Additionally, low levels of experience and skills are significant contributors to youth unemployment because the demand for young workers is generally lower than its supply (Gomez-Salvador et al., 2008). This could be explained by the presence of a mismatch between the youths' capabilities and the skills required to obtain certain positions. In this case, employers are having a difficult time finding the right competences and working experiences within the youth labor force. It was therefore important to identify a successful proxy to represent skill training of youths. (This was determined to be the real spending of the Employment and Training Administration, which is an agency within the Department of Labor). This agency supports programs providing youths with the necessary skills and training that employers are looking for and youths will need going forward in their careers. This therefore provides the model with a good measure of government spending devoted towards the career and skill development of youths.

As is evident in the model illustration, there are several theoretical expectations for the signs of the estimated coefficients. Most notably, it was expected that the estimated coefficient for YUR $\mathrm{Y}_{\mathrm{t}-1}$ would be positive because if the past youth unemployment rate increases, the present youth unemployment rate should increase as well, given the theory behind the scarring effect. However, one interesting component of the model is that the real GDP per capita independent variable takes logarithmic form, which was done to condense the data, but because of the complex nature of this variable, some work will need to be completed in order to achieve a logical interpretation of its coefficient. It is also important to note that the IV Method was used to estimate this model because there was reason to believe that the $\mathrm{YUR}_{\mathrm{t}-1}$ variable was a stochastic regressor, or correlated with the error term, because it was directly calculated from the dependent variable and appears on the right-hand side of the model. The following instruments were chosen for the lagged youth unemployment rate: 

INFLA $_{\mathrm{t}-1}$ : $\quad$ inflation (from previous quarter) lagged by one quarter
TRAIN $\mathrm{t}_{\mathrm{t}-1}$ : real spending of Employment and Training Administration (ETA) (millions) lagged by one quarter
EDUC $_{\mathrm{t}-1}$ : $\quad$ real budget of the Department of Education (millions) lagged by one quarter

While INFLA $A_{t-1}$ picks up on the price level from the previous quarter, TRAIN $\mathrm{t}_{\mathrm{t}-1}$ brings in the lagged effect of spending on training programs, and $\mathrm{EDUC}_{\mathrm{t}-1}$ addresses past government spending on education. Through testing, it was concluded that these were strong instruments and the model was not over-identified, so they were utilized in the final sub-models within Model 1 to instrument out the YUR $\mathrm{Y}_{\mathrm{t}-1}$ variable and produce more reliable estimates.

In addition to a more general model using national youth unemployment data, this model also estimates additional sub-models which capture differences between genders and races. This is important because it is assumed that differences in gender and race are reflected in the youth unemployment rate (Freeman et al., 1982). Looking purely at national data would not provide much useful insight due to the fact that the population is not weighted equally across the country. In fact, because it is believed that there are differences in the labor force behavior exhibited by men and women as well as by Whites, Blacks, and Hispanics, the overall model that uses combined data would be less useful in directing potential policy changes. Thus, it was important to separate the analysis of these demographic groups to better understand the underlying issues at play and so that policy recommendations could be more effectively targeted towards different groups of people.

B. Model 2 - Using EARN ${ }_{t}$ as the Dependent Variable: As mentioned previously, it was important to also estimate a model using a measure of earnings as the dependent variable, with the lagged youth unemployment rate appearing on the other side in order to learn more about early past unemployment's influence on future earnings. As one can see below, Model 2 has many similarities to Model 1, but there are some differences, the most notable of which are $\mathrm{EARN}_{\mathrm{t}}$ as the dependent variable and the incorporation of the fourth lag of the youth unemployment rate instead of the first. Model 2 can be seen below with the sign expectations for each estimated coefficients.

$$
\begin{gathered}
(-) \quad(+) \quad(+) \\
E A R N_{\mathrm{t}}=\beta_{0}+\beta_{1} Y U R_{t-4}+\beta_{2} \ln G D P_{\mathrm{t}}+\beta_{3} M W_{\mathrm{t}}+\beta_{4} H S_{-} G R A D S_{\mathrm{t}}+\beta_{5} Y L F P R_{\mathrm{t}} \\
(+) \\
+\beta_{6} H R S_{-} W R K_{\mathrm{t}}+\beta_{7} O U T_{-} H R_{\mathrm{t}}+\varepsilon_{\mathrm{t}}
\end{gathered}
$$

EARN $_{\mathrm{t}} \quad \quad$ real median weekly youth earnings ${ }^{3}$

YUR $\mathrm{H}_{\mathrm{t}} \quad$ youth unemployment rate

\footnotetext{
${ }^{3} \mathrm{EARN}_{\mathrm{t}}$ takes on different values depending on the specific gender/race model. For example, in the male sub-model, $E A R N_{t}$ is real median weekly earnings for youth males. The same is true for $\mathrm{YUR}_{\mathrm{t}-4}$.
} 
GDP: $\quad$ real GDP per capita

$\mathrm{MW}_{\mathrm{t}}$ : $\quad$ real Federal minimum wage

HS_GRADS : number of youths with a high school diploma (millions)

YLFPR $_{\mathrm{t}}$ : $\quad$ youth labor force participation rate

HRS_WRK : average hours worked per week for youths

OUT_HRt: youth output per hour

Model 2 utilizes the fourth lag of the youth unemployment rate because it is presumed that the earnings aspect of the scarring effect is more delayed than that of the unemployment component. Additionally, because $\mathrm{YUR}_{\mathrm{t}-1}, \mathrm{YUR}_{\mathrm{t}-2}$, and $\mathrm{YUR}_{\mathrm{t}-3}$ were not jointly significant, it suggests that the first three lags of the youth unemployment rate did not have a statistically significant relationship with EARN $\mathrm{N}_{\mathrm{t}}$ It was therefore necessary to use the fourth lag and exclude the previous three lags. Model 2 also incorporates both $\operatorname{lnGDP}_{\mathrm{t}}$ and $\mathrm{MW}_{\mathrm{t}}$, which appear in Model 1 because of their supposed effect on youth earnings as well as the youth unemployment rate. However, because this model had a problem with endogeneity, specifically with youth output per hour (OUT_HR $)$, the IV Method was adopted again. The instruments below were believed to tell a good story about OUT_HR $\mathrm{t}_{\mathrm{t}}$ because they pick up on technology and capital consumption respectively, both of which contribute to the level of output (Kabaklarli et al., 2011):

UTIL_PAT: number of utility patents

CONS_CAP: real consumption of fixed capital (billions)

Through testing, it was concluded that these were strong instruments and the model was not overidentified, so they were utilized in the final sub-models within Model 2 to instrument out the OUT_HR variable and produce more reliable estimates.

Similar to the first model, Model 2 was estimated not only on the national level, but also broken down by gender and race. Again, this was done in order to capture the unique differences between these groups because of the assumed differences between how past youth unemployment affects current earnings for each sub-section of the population. Through this approach, it was hoped that policy changes could be better directed to benefit each demographic group.

By including Model 1 and Model 2, both sides of the scarring effect (i.e., increase in future unemployment and decrease in future earnings) could be illustrated numerically. Through the estimation of these models, the extent to which the scarring effect exists in both of its aspects will become much clearer. Because of the consequences brought about by the presence of this economic phenomenon, it is crucial to draw conclusions from both of these models and generate logical policy recommendations in order to promote a friendlier labor market environment for youths in which the strength of the scarring effect is lessened. 


\section{EMPIRICS}

Quarterly data covering the period from 1980 to 2013 was used to analyze the estimated impact of various economic factors on the youth unemployment rate and youth earnings in the United States. This time period was chosen so that the study could inspect recent developments regarding the scarring effect, while accounting for structural changes in the economy by examining a large period of time. Additionally, quarterly data was chosen over yearly data because it led to more observations and could produce more specific conclusions regarding the length of time it takes for the scarring effect to appear for youths. Data was extracted primarily from the following sources: Bureau of Labor Statistics, ${ }^{4}$ Federal Reserve Economic Data, ${ }^{5}$ Census Bureau, Bureau of Economic Analysis, ${ }^{6}$ Department of Education, ${ }^{7}$ and Department of Labor. ${ }^{8}$ These same data sources were referenced for all of the models in the current study.

A. Summary Statistics for Model 1: Table 1 illustrates the summary statistics for the select variables used in Model 1. Please note that those variables appearing above the line represent different variations in the dependent variable depending on the specific sub-model (i.e., the overall, gender-related, or race-related youth unemployment rate), while those variables beneath the line represent the independent variables used in every sub-model. ${ }^{9}$

Table 1: Summary Statistics for Model 1

\begin{tabular}{|c|c|c|c|}
\hline & Obs. & Mean & Std. Dev. \\
\hline \multicolumn{4}{|l|}{ Variable } \\
\hline $\mathrm{YUR}_{\mathrm{t}}$ & 134 & 13.07761 & 2.596575 \\
\hline MYUR $_{t}$ & 134 & 14.01343 & 3.104539 \\
\hline FYUR $_{t}$ & 134 & 12.06269 & 2.203336 \\
\hline WYURt $_{\mathrm{t}}$ & 134 & 11.21567 & 2.407846 \\
\hline BYURt $_{t}$ & 134 & 25.45224 & 4.736988 \\
\hline HYUR $_{t}$ & 134 & 20.5209 & 5.173851 \\
\hline ADULT & 134 & 5.173851 & 1.549514 \\
\hline $\operatorname{lnGDP} t$ & 134 & 10.58467 & 0.182048 \\
\hline $\mathrm{MW}_{\mathrm{t}}$ & 134 & 2.046866 & .5557524 \\
\hline INFLA $_{t}$ & 134 & .780597 & .6668834 \\
\hline TRAIN $_{\mathrm{t}}$ & 134 & 21.41937 & 4.427315 \\
\hline
\end{tabular}

In terms of the dependent variables utilized in the various sub-models, on average, youth males have a higher unemployment rate than youth female, with Blacks and Hispanics tending to have significantly

\footnotetext{
${ }^{4}$ Bureau of Labor Statistics, United States Department of Labor, http://www.bls.gov.

5 Economic Research: Federal Reserve Bank of St. Louis, Federal Reserve Economic Data, http://www.research.stlouisfed.org.

${ }^{6}$ Bureau of Economic Analysis, United States Department of Commerce, http://www.bea.gov.

${ }^{7}$ United States Department of Education, http://www.ed.gov.

${ }^{8}$ United States Department of Labor, http://www.dol.gov.

9 YUR: overall youth unemployment rate, MYUR : male youth unemployment rate, FYUR: female youth unemployment rate, WYURt: White youth unemployment rate, BYUR $R_{t}$ : Black youth unemployment rate, HYUR: Hispanic youth unemployment rate, and $\mathrm{ADULT}_{\mathrm{t}}$ : adult unemployment rate.
} 
higher youth unemployment rates than Whites. This matches the expectations one would have because youth females may be more likely to drop out of the labor force entirely if unable to find a job. Females in general have been more favored in recent years by employers due to affirmative action and the perception of a harder female work ethic. It is also important to note that females tend to be less adversely affected by economic downturns. Moreover, because males receive a higher wage than females on average, it makes sense that young males would have a more difficult time finding work given their similar skill and experience levels to females. Another reason for the higher male youth unemployment rate could be seen during the most recent recession where most of the jobs lost were in goods-producing sectors versus both healthcare and education industries. The manufacturing sectors have a higher concentration of male workers compared to healthcare and education industries, which employ more female workers. (Gregg and Tominey, 2005).

It is also logical that Blacks and Hispanics experience a higher youth unemployment rate than Whites, on average, because of generally lower levels of education, the shorter tenure of the occupations and industries in which they work, and the tendency to cluster in geographic locations that lend themselves to worse job opportunities. Even more so, this can be explained by the racial disparities that have been present throughout America's history that continue to affect minorities in many ways. Because minority youths are likely to have had less economic and educational opportunities as a result of higher levels of discrimination and lower levels of wealth from previous generations, they are more likely to experience unemployment early on in their professional careers. Furthermore, once these minority youths actually obtain positions, discrimination in the workplace also contributes to youth unemployment because of the desire to leave a current position and search for a more comfortable and less discriminatory work environment (Hills, 1990).

Additionally, when comparing the means of the youth and adult unemployment rates, it is apparent that youths suffer from a much higher unemployment rate, on average. This is understandable because youths tend to be more dramatically affected during economic downturns, in terms of unemployment and other economic measures. This relationship may also arise because of the higher relative unemployment durations experienced by youths, the concentration of youths in cyclically sensitive sectors of the economy, and the more fragile employment contracts (i.e., temporary and part-time contracts) of young workers (Choudhry et al., 2012). Finally, the means and ranges of the remaining independent variables used in the model all make sense theoretically, given their conversion into real terms; however, one note is that the $\mathrm{MW}_{\mathrm{t}}$ independent variable represents the real federal minimum wage and does not account for state minimum wage regulations. Also, when looking at the data for $\mathrm{MW}_{\mathrm{t}}$, it is apparent that the variable takes on the same value for an amount of time, then takes on a new value for another amount of time, and proceeds to follow the same pattern because of the way in which the federal minimum wage is assigned a new value by the government every so often. Therefore, this variable is characterized by a unique pattern of values. ${ }^{10}$ 
B. Empirical Results and Analysis for Model 1: The major econometric issues plaguing the OLS model were first-order autocorrelation and the presence of a stochastic regressor. Table 2 shows regression results for Model 1 that address the presence of these two econometric issues through the inclusion of an AR(1) term and the use of the IV Method. Further there was not enough conclusive evidence to suggest that the sub-models in Model 1 suffered from non-stationarity, and they were all estimated in a levels space. The final revised results that are presented in Table 2:

Table 2: Regression Results (Model 1: dependent variable = youth

\begin{tabular}{|c|c|c|c|c|c|c|}
\hline Dependent variable: & $\frac{\text { Overall( }=}{\frac{\text { YUR }}{\mathrm{t}} \mathrm{t}}$ & $\frac{\frac{\text { Male(= }}{\text { MYUR) }}}{\text { (ii) }}$ & $\frac{\text { Female(= }}{\frac{\text { FYUR) }}{\text { (iii) }}}$ & $\begin{array}{c}\frac{\text { White(= }}{\text { WYUR) }} \\
\text { (iv) }\end{array}$ & $\frac{\frac{\operatorname{Black}(=}{\text { BYUR })}}{(\mathrm{v})}$ & $\frac{\text { Hispanic(= }}{\frac{\text { HYUR) }}{(\mathrm{vi})}}$ \\
\hline \multicolumn{7}{|l|}{ Independent variables } \\
\hline$\wedge \mathrm{UR}_{\mathrm{t}-1}$ & $\begin{array}{c}0.5110^{* * *} \\
(0.1519)\end{array}$ & $\begin{array}{c}0.8904^{* * *} \\
(0.2051)\end{array}$ & $\begin{array}{l}-0.0599 \\
(0.1543)\end{array}$ & $\begin{array}{c}0.6382 * * * \\
(0.1956)\end{array}$ & $\begin{array}{c}0.1222 \\
(0.1460)\end{array}$ & $\begin{array}{c}0.2554 \\
(0.1737)\end{array}$ \\
\hline $\mathrm{ADULT}_{\mathrm{t}}$ & $\begin{array}{c}1.2196^{* * * *} \\
(0.0855)\end{array}$ & $\begin{array}{c}1.2785^{* * *} \\
(0.1404)\end{array}$ & $\begin{array}{c}1.0903^{* * *} \\
(0.0881)\end{array}$ & $\begin{array}{c}1.0336 * * * \\
(0.0996)\end{array}$ & $\begin{array}{c}2.2842^{* * * *} \\
(0.1954)\end{array}$ & $\begin{array}{l}0.9939 * * * \\
(0.3469)\end{array}$ \\
\hline $\operatorname{lnGDP} P_{t}$ & $\begin{array}{c}-8.4220 * * * \\
(1.9546)\end{array}$ & $\begin{array}{c}-12.9259 * * * \\
(3.2304)\end{array}$ & $\begin{array}{c}-5.5827 * * * \\
(1.4936)\end{array}$ & $\begin{array}{c}-9.0308 * * * \\
(2.3268)\end{array}$ & $\begin{array}{c}-12.8619 * * * \\
(3.5989)\end{array}$ & $\begin{array}{c}-28.0212 * * * \\
(6.9352)\end{array}$ \\
\hline $\mathrm{MW}_{\mathrm{t}}$ & $\begin{array}{c}2.0849 * * * \\
(0.4355)\end{array}$ & $\begin{array}{c}2.7410^{* * * *} \\
(0.6328)\end{array}$ & $\begin{array}{c}1.5748^{* * *} \\
(0.4419)\end{array}$ & $\begin{array}{c}2.3211^{* * *} \\
(0.4556)\end{array}$ & $\begin{array}{c}0.0561 \\
(1.2189)\end{array}$ & $\begin{array}{c}2.0193 \\
(2.1424)\end{array}$ \\
\hline INFLA $_{t}$ & $\begin{array}{c}0.2592^{* * * *} \\
(0.0869)\end{array}$ & $\begin{array}{c}0.1109 \\
(0.1551)\end{array}$ & $\begin{array}{c}0.4354 * * * \\
(0.1124)\end{array}$ & $\begin{array}{c}0.2474 * * * \\
(0.1103)\end{array}$ & $\begin{array}{c}0.5158 * * * \\
(0.1797)\end{array}$ & $\begin{array}{c}0.1036 \\
(0.2102)\end{array}$ \\
\hline TRAIN $_{\mathrm{t}}$ & $\begin{array}{c}0.1533^{* * * *} \\
(0.0516)\end{array}$ & $\begin{array}{c}0.2821 * * * \\
(0.0817)\end{array}$ & $\begin{array}{c}0.0103 \\
(0.0521)\end{array}$ & $\begin{array}{c}0.1615^{* * *} \\
(0.0576)\end{array}$ & $\begin{array}{l}0.1546^{*} \\
(0.0907)\end{array}$ & $\begin{array}{c}0.3448^{* * *} \\
(0.1312)\end{array}$ \\
\hline $\operatorname{AR}(1)$ & $\begin{array}{c}0.1839 * * * \\
(0.0688)\end{array}$ & $\begin{array}{c}0.0997 \\
(0.0642)\end{array}$ & $\begin{array}{c}0.2629^{* * *} \\
(0.0772)\end{array}$ & $\begin{array}{c}0.1490 * * \\
(0.0689)\end{array}$ & $\begin{array}{c}0.3562 * * * \\
(0.0934)\end{array}$ & $\begin{array}{c}0.6022 * * * \\
(0.0816)\end{array}$ \\
\hline _Constant & $\begin{array}{c}81.2805^{* * *} \\
(17.9185)\end{array}$ & $\begin{array}{c}119.7921^{* * * *} \\
(29.9708)\end{array}$ & $\begin{array}{c}62.2806 * * * \\
(13.9356) \\
\end{array}$ & $\begin{array}{c}85.7268 * * * \\
(21.4554) \\
\end{array}$ & $\begin{array}{r}142.4833^{* * * *} \\
(36.9605) \\
\end{array}$ & $\begin{array}{c}294.9931 * * * \\
(72.5204) \\
\end{array}$ \\
\hline No. of Obs. & 134 & 134 & 134 & 134 & 134 & 134 \\
\hline R-Squared & 0.9358 & 0.9015 & 0.9076 & 0.9150 & 0.9031 & 0.8320 \\
\hline
\end{tabular}

${ }^{*} \mathrm{p}<0.10, * * \mathrm{p}<0.05, * * * \mathrm{p}<0.010$

Newey West standard errors ( )

$\wedge$ appropriate lagged dependent variable is generated by an IV method

(i) Analysis of Overall Model: The most notable conclusion from the overall sub-model is the positive sign of the $\mathrm{YUR}_{\mathrm{t}-1}$ estimated coefficient and its statistical significance because of the implications for the scarring effect. Because this coefficient is positive, the model suggests that, on the national level, an increase in past youth unemployment is estimated to lead to an increase in current youth unemployment. Even though $\mathrm{YUR}_{\mathrm{t}-1}$ is lagged only one quarter behind the current time period, there is still enough statistically significant evidence to suggest the existence of the scarring effect. However, despite these results, it is difficult to draw conclusions on the individual youth level because this study looks at the United States as a whole. That is, one cannot completely trace the experiences of individuals and therefore point to specific instances of the scarring effect. Rather, one can just generalize the overall existence of the scarring 
effect because the results cannot be disentangled to illustrate an individual story. Nevertheless, this result suggests an overall national relationship, and even though the scarring effect may exist for some individuals and not for others, on the whole, according to these results, past youth unemployment leads to future youth unemployment within the United States.

Although the focus of this study is to look at the scarring effects brought about by youth unemployment, there are also many other useful findings that result from the estimated coefficients of the independent variables in Model 1. For example, the positive estimated coefficient for ADULT $\mathrm{t}_{\mathrm{t}}$ suggests that the youth and adult unemployment rates tend to move in similar patterns. This makes sense theoretically because adults and youths share many of the same factors that influence their unemployment rates; where they differ most is the extent to which these factors affect the respective unemployment rate value. Another interesting conclusion from this estimated coefficient for $\mathrm{ADULT}_{\mathrm{t}}$ (i.e., 1.2196) is that it exceeds 1 . So if the adult unemployment rate increases by one percentage point, on average the youth unemployment rate is estimated to increase by 1.2196 percentage points. This illustrates that changes in the youth unemployment rate are more dramatic than those for the adult unemployment rate. This supports the comparison above.

It is also logical that the real GDP per capita independent variable has a negative statistically significant relationship with the youth unemployment rate because as the economy grows, unemployment usually decreases, regardless of whether one is examining youths or adults. The overall model also predicts a positive relationship between the real federal minimum wage and the current youth unemployment rate. According to economic theory, a wage set higher than the rate normally prevailing in the market will lead to a surplus number of workers seeking employment. Because of the lack of skills and experience of young workers, they are the most likely to receive the minimum wage and therefore suffer the consequences of an increase of this value on employment prospects. Thus, it makes sense that the estimated coefficient for $\mathrm{MW}_{\mathrm{t}}$ would be positive (Freeman et al., 1982). This model produces a positive sign for the estimated coefficient of INFLA $_{t}$. The expected direction of the relationship between the youth unemployment rate and inflation is somewhat unclear; however, the long-run Philips Curve provides justification for a positive relationship. So even though the relationship between these two economic factors is fairly complex, there is plausible reasoning for the estimated sign (Kabaklarli et al., 2011).

Finally, the overall model suggests a positive relationship between the real spending of the Employment and Training Administration and the youth unemployment rate, but this seems slightly counterintuitive. One may ask: Shouldn't increases in spending on training lead to a decrease in youth unemployment because the lack of skills is what was originally hindering youths from obtaining these positions? Why are most policy recommendations geared towards increasing the skills of youths if this model suggests that this action is actually harmful? These are very valid concerns about the model, thus pulling the positive sign of this estimated coefficient into question. One explanation for why the negative sign is not appearing is because the ultimate effects of training spending on the youth unemployment rate are delayed 
and will not be felt in the current time period (Hills, 1990). That is, if spending on training is increased right now, it is unlikely to immediately reduce youth unemployment. Once this amount of spending is raised, youths actually have to complete the training before any effect is going to be felt in terms of their employment status. Therefore, because this model is only looking at spending on training in the current time period, it is less worrisome that there is a positive sign, but some doubt still remains.

The following provides further potential justification for the positive sign of the TRAIN $\mathrm{t}_{\mathrm{t}}$ estimated coefficient. One reason why this sign could make sense is because higher levels of youth training may dissuade companies from hiring these previously unskilled laborers. Because of youths' general lack of skills, companies tend to hire from this age group to fill low-paying, unskilled positions. In other words, one of the main motivators for employers to hire young people is because they are inexpensive labor that can be used to fill these positions. But if youths were to become more skilled, they may expect higher pay than what they are currently receiving, making them less attractive to employers and ultimately increasing their unemployment rate. Another contributor to this positive relationship could be that competition for jobs amongst youths might increase because of the greater average skill level of those competing for similar positions. This unexpected sign could also arise because of a need to change the approach to training; instead of concluding that training in general leads to higher youth unemployment in the current time period, one could conclude that the current training programs have not had the desired effect so far, but through minor adjustments, the wanted results may begin to appear. Even though there is this justification for the positive sign, one still has to be wary about this situation.

Nevertheless, both the individual and overall statistical significance measures suggest that this is a strong model to estimate the effects of economic factors on the youth unemployment rate at the national level as all of estimated coefficients were statistically significant.

From the results of the overall youth unemployment rate model, one can conclude that the unemployment component of the scarring effect does exist nationally because of the positive value of the estimated coefficient for the lagged youth unemployment rate. However, the overall model does not segment the population, allowing us to overlook the assumption that the youth unemployment rate reacts differently to economic variables depending on demographic categorization, such as gender and race. Thus, it was crucial to also look at other models that divide the population into different sub-groups in order to produce more directed policy recommendations.

(ii) Analysis of Gender and Race: The sub-models broken down by gender and race produce similar results to the overall model, given that they all react in generally the same manner to economic factors although they react to these factors to different degrees, which is where most of the conclusions can be drawn.

For example, when looking at the estimated coefficient for the lagged youth unemployment rate, the sign is positive for the male, White, Black, and Hispanic sub-models. The only exception is in the female 
model, where it takes on a negative, statistically insignificant estimated coefficient. Nevertheless, through a comparison of the magnitude of these scarring effect coefficients across genders and races, it is suggested that males experience a greater scarring effect than females in terms of future unemployment, whereas Whites experience it the greatest, followed by Hispanics and then Blacks. It should be noted however that the Black and Hispanic sub-models also have statistically insignificant results, therefore producing nondefinitive results, but unlike in the female model, these statistically insignificant coefficients are positive. It is important to note that this study is not suggesting a conclusion about the scarring effect in either direction for female, Black, or Hispanic youths; rather, there is simply not enough statistically significant evidence to conclude anything either way.

Model 1 only looks at the scarring effect felt one quarter in the future, so there may be slightly different coefficients in later quarters. But given the results of the current model, it appears that males and Whites are the only ones who definitely feel the future unemployment part of the scarring effect. This is an interesting result because males and Whites are generally thought to be the most successful demographic groups in the labor market, but this model suggests that they experience the scarring effect to the greatest extent. One potential justification for this outcome is that because males and Whites generally fare better in terms of employment opportunities, the scarring effect is more prominent when future unemployment occurs following previous unemployment (Gregg et al., 2005). On the opposite side of the situation, because females, Blacks, and Hispanics are historically known to have a more difficult experience in the labor market, it is harder to isolate instances of unemployment and definitely conclude that one led to the other. Rather, it could just be that these demographic groups are more likely to experience career obstacles, so future unemployment cannot necessarily be attributed to the scarring effect. In other words, it is a result of the unfortunate tendencies present in the labor market for these groups. As mentioned previously, conclusions about the scarring effect for females and these minority groups cannot be made in either direction.

Additional lagged terms were added to the model throughout the data analysis process, yet this not only took away from the overall strength of the model but also failed to show significant scarring effect results. In the future it may be interesting to look at five or ten years in the future and see how the various groups compare at that time. Nevertheless, it can be concluded that the scarring effect does exist regarding future unemployment for male and White youths, but the effect is unclear for female, Black, and Hispanic youths.

All of the sub-models have high individual and overall statistical significance and produce the expected signs for the large majority of the estimated coefficients. As a result of the statistically insignificant nature of the $\mathrm{YUR}_{\mathrm{t}-1}$ estimated coefficient in the female, Black, and Hispanic sub-models, it is difficult to draw reliable and logical conclusions about how future unemployment is affected by early unemployment. 
(iii) Main Takeaway: Based on all of the sub-models within Model 1, it is apparent that the future unemployment part of the scarring effect does exist for the nation as a whole, males, and Whites, with less evidence being available for females, Blacks, and Hispanics.

C. Summary Statistics for Model 2: Because the scarring effect is comprised of two parts (i.e., increased future youth unemployment rate and decreased future youth earnings as a result of past youth unemployment), it was necessary to construct a second model to capture the earnings component of this economic phenomenon that was not examined in Model 1. Similar to the previous model, Model 2 breaks down its sample into gender and race components in order to pick up on unique differences across the population and to produce more targeted policy recommendations. As a result of this different look at the scarring effect, it was necessary to generate additional summary statistics that are displayed below in Table 3. The overall, gender, and race summary statistics for EARN $N_{t}$ and $\mathrm{YUR}_{\mathrm{t}}$ are displayed in the table, along with more information on the other variables.

Table 3: Summary Statistics for Model 2

\begin{tabular}{lccc}
\hline \hline & Obs. & Mean & Std. Dev. \\
\hline Variable & & & \\
EARN $_{\mathrm{t}}$ & 131 & 327.5038 & 82.70715 \\
M_EARN $_{\mathrm{t}}$ & 131 & 351.3817 & 82.78847 \\
F_EARN $_{\mathrm{t}}$ & 131 & 320.5038 & 82.70516 \\
W_EARN $_{\mathrm{t}}$ & 131 & 339.5038 & 82.70516 \\
B_EARN $_{\mathrm{t}}$ & 131 & 316.3893 & 82.78151 \\
H_EARN $_{\mathrm{t}}$ & 131 & 313.5038 & 82.70516 \\
\hline YUR $_{\mathrm{t}-4}$ & 131 & 13.01069 & 2.580169 \\
MYURt-4 $_{\text {FYUR }}$ & 131 & 13.92672 & 3.082926 \\
WYUR $_{\mathrm{t}-4}$ & 131 & 12.01908 & 2.200389 \\
BYURt-4 $_{\text {HYUR }}$ & 131 & 11.15573 & 2.39259 \\
HYd $_{\text {lnGDP }}$ & 131 & 25.43817 & 4.777567 \\
MW $_{\mathrm{t}}$ & 131 & 20.65420 & 5.183291 \\
HS_GRADS $_{\mathrm{t}}$ & 131 & 10.59219 & 0.17706 \\
YLFPR $_{\mathrm{t}}$ & 131 & 2.062443 & 0.55227 \\
HRS_WRK $_{\mathrm{t}}$ & 131 & 22.20118 & 2.60637 \\
& 131 & 63.67481 & 4.99234 \\
& 131 & 39.67481 & 1.03383
\end{tabular}

The values of these summary statistics make sense. For example, the real median weekly youth earnings of males exceed that of females, on average, and White youths have higher earnings than Black and Hispanic youths. These results are logical because males tend to earn more than females, and majority races tend to earn more than minority races. From these results, it is apparent that these relationships not only hold true for the entire American population (youths and adults combined) but also for the youth population on its own.

D. Empirical Results and Analysis: The estimated regression results for Model 2 are displayed below in Table 4, with a gender and race breakdown similar to Model 1. Other similarities with Model 1 
include the incorporation of an AR(1) term in all of the sub-models in order to produce more reliable standard errors and the instrumentation of an endogenous variable (i.e., OUT_HR ${ }_{t}$ ) through the IV Method. One interesting aspect of Model 2 is that it includes only YUR $\mathrm{Y}_{\mathrm{t}-4}$, excluding $\mathrm{YUR}_{\mathrm{t}-1}, \mathrm{YUR}_{\mathrm{t}-2}$, and $\mathrm{YUR}_{\mathrm{t}-3}$. Because the previous three lagged terms were not jointly significant and the scarring effect only began showing up after the fourth lag, it was decided to only include $\mathrm{YUR}_{\mathrm{t}-4}$ in the model.

Table 4: Regression Results (Model 2 - dependent variable: earnings)

\begin{tabular}{|c|c|c|c|c|c|c|}
\hline Dependent variable: & $\frac{\text { Overall(= }}{\frac{\text { EARN) }}{(\mathrm{i})}}$ & $\frac{\begin{array}{c}\text { Male(= } \\
\text { M_EARN) }\end{array}}{\text { (ii) }}$ & $\begin{array}{c}\frac{\text { Female(= }}{\underline{\text { F_EARN) }}} \\
\text { (iii) }\end{array}$ & $\begin{array}{c}\frac{\text { White( }=}{\text { W_EARN) }} \\
\frac{\text { (iv) }}{}\end{array}$ & $\frac{\underline{\text { Black }(=}}{\underline{\text { B_EARN })}}$ & $\begin{array}{c}\frac{\text { Hispanic( }}{\text { H_EARN) }} \\
\text { (vi) }\end{array}$ \\
\hline \multicolumn{7}{|l|}{ Independent variables } \\
\hline$\# \mathrm{UR}_{\mathrm{t}-4}$ & $\begin{array}{c}-6.0569 * * * \\
(0.9298)\end{array}$ & $\begin{array}{c}-5.1974 * * * \\
(1.0465)\end{array}$ & $\begin{array}{c}-6.1265 * * * \\
(0.5793)\end{array}$ & $\begin{array}{c}-6.1042^{* * *} \\
(1.4303)\end{array}$ & $\begin{array}{c}-3.2674 * * * \\
(0.5402)\end{array}$ & $\begin{array}{c}-2.4722 * * * \\
(0.7505)\end{array}$ \\
\hline $\operatorname{lnGDP}_{t}$ & $\begin{array}{c}19.9410 \\
(49.1567)\end{array}$ & $\begin{array}{c}33.6436 \\
(60.7866)\end{array}$ & $\begin{array}{c}134.4329 * \\
(65.1690)\end{array}$ & $\begin{array}{c}51.0169 \\
(54.1396)\end{array}$ & $\begin{array}{c}36.5040 \\
(70.2948)\end{array}$ & $\begin{array}{c}192.3403 * * * \\
(36.6314)\end{array}$ \\
\hline $\mathrm{MW}_{\mathrm{t}}$ & $\begin{array}{c}37.5982 * * * \\
(13.0217)\end{array}$ & $\begin{array}{c}36.1671^{* * *} \\
(13.4578)\end{array}$ & $\begin{array}{c}42.1090 * * * \\
(65.1690)\end{array}$ & $\begin{array}{c}34.6027^{* *} \\
(13.5883)\end{array}$ & $\begin{array}{c}26.7443^{* *} \\
(11.4819)\end{array}$ & $\begin{array}{c}38.7368^{* *} \\
(17.8574)\end{array}$ \\
\hline HS_GRADS ${ }_{\mathrm{t}}$ & $\begin{array}{c}2.3438 \\
(2.3616)\end{array}$ & $\begin{array}{c}1.9160 \\
(1.9260)\end{array}$ & $\begin{array}{c}5.7758^{* * * *} \\
(7.8133)\end{array}$ & $\begin{array}{c}2.1126 \\
(1.5821)\end{array}$ & $\begin{array}{c}2.8198 \\
(2.6902)\end{array}$ & $\begin{array}{c}0.9565 \\
(0.7959)\end{array}$ \\
\hline YLFPR $_{\mathrm{t}}$ & $\begin{array}{l}-0.9738 \\
(1.7485)\end{array}$ & $\begin{array}{l}-2.2226 \\
(1.7622)\end{array}$ & $\begin{array}{l}-0.5618 \\
(2.1383)\end{array}$ & $\begin{array}{l}-1.9423 \\
(1.4537)\end{array}$ & $\begin{array}{l}-0.4608 \\
(1.5468)\end{array}$ & $\begin{array}{c}-2.2482 * * * \\
(0.7360)\end{array}$ \\
\hline HRS_WRK & $\begin{array}{c}2.6627 \\
(2.0211)\end{array}$ & $\begin{array}{c}3.3605 \\
(2.3694)\end{array}$ & $\begin{array}{c}2.6573 \\
(1.1653)\end{array}$ & $\begin{array}{c}1.6551 \\
(2.3166)\end{array}$ & $\begin{array}{c}2.7396 \\
(2.1428)\end{array}$ & $\begin{array}{c}1.5548 \\
(3.3088)\end{array}$ \\
\hline$\wedge \mathrm{OUT} \_\mathrm{HR}_{\mathrm{t}}$ & $\begin{array}{c}3.2523 * * * \\
(0.6185)\end{array}$ & $\begin{array}{c}2.9853 * * * \\
(0.7735)\end{array}$ & $\begin{array}{c}1.6405 \\
(1.8218)\end{array}$ & $\begin{array}{c}2.7982 * * * \\
(0.5447)\end{array}$ & $\begin{array}{c}3.0973^{* * * *} \\
(1.0388)\end{array}$ & $\begin{array}{c}0.6335 \\
(0.5872)\end{array}$ \\
\hline $\operatorname{AR}(1)$ & $\begin{array}{c}0.2285 \\
(0.2068)\end{array}$ & $\begin{array}{c}0.2506 \\
(0.1787)\end{array}$ & $\begin{array}{c}0.0665 \\
(1.0935)\end{array}$ & $\begin{array}{c}0.2815 \\
(0.1823)\end{array}$ & $\begin{array}{c}0.1723 \\
(0.1813)\end{array}$ & $\begin{array}{c}0.4478^{* * *} \\
(0.0828)\end{array}$ \\
\hline _Constant & $\begin{array}{l}-230.1188 \\
(513.2140)\end{array}$ & $\begin{array}{l}-296.5611 \\
(512.5218)\end{array}$ & $\begin{array}{c}-1434.647 * * \\
(634.0013)\end{array}$ & $\begin{array}{l}-421.7099 \\
(418.6013)\end{array}$ & $\begin{array}{l}-413.1981 \\
(700.8769)\end{array}$ & $\begin{array}{c}-1727.048^{* * *} \\
(282.7010)\end{array}$ \\
\hline No. of Obs. & 131 & 131 & 131 & 131 & 131 & 131 \\
\hline R-Squared & 0.9885 & 0.9883 & 0.9829 & 0.9909 & 0.9870 & 0.9902 \\
\hline
\end{tabular}

${ }^{*} \mathrm{p}<0.10, * * \mathrm{p}<0.05, * * * \mathrm{p}<0.010$

Newey West standard errors ( )

\# appropriate lagged unemployment

$\wedge$ generated by an IV method

(i) Analysis of Overall Model: There are many interesting conclusions that can be drawn from the overall model, the most important of which pertains to the the scarring effect. If there is an increase in past youth unemployment, the scarring effect suggests that this would result in a decrease in future earnings. In order to illustrate this phenomenon, the fourth lagged term of the youth unemployment rate was included in the model. A UR term that was lagged by four time periods was used because the effects on earnings are more delayed than for the effects on the current youth unemployment rate. In fact, when any fewer than four lags were included in the model, the estimated coefficients had the opposite signs of what one would expect. 
It was only after four lags that the scarring effect appeared. As one can see in the overall model, the fourth lagged term's estimated coefficient is negative and statistically significant; therefore, overall it is estimated that the scarring not only exists but is delayed by four quarters (i.e., one year) in terms of earnings.

Meanwhile, the estimated coefficient for $\operatorname{lnGDP}_{t}$ has a positive value, which makes sense because growth in the economy is typically accompanied by higher wages, on average. Another variable that appears in both Model 1 and Model 2, in addition to $\operatorname{lnGDP}_{t}$, is the real federal minimum wage. This estimated coefficient also has a positive value, which is theoretically plausible because the minimum wage is a form of earnings that is generally offered to youth workers. If the minimum wage increases, it would be expected that real median weekly youth earnings would increase as well.

HS_GRADS ${ }_{t}$ was intended to pick up on the average education level of youths, based on the number of youths with a high school diploma (millions). This coefficient is estimated to have a positive sign, which again is logical because if more youths are educated, they are more likely to obtain higher paying positions and earn more money as a result. It also makes sense that the $\mathrm{YLFPR}_{t}$ estimated coefficient would be negative because if a higher proportion of youths are participating in the labor force, then their earnings should fall. Although the positive coefficient for HRS_WRK $\mathrm{t}_{\mathrm{t}}$ is statistically insignificant, this sign is what would be expected because longer working hours should be compensated with higher earnings, either because these youths are paid on an hourly basis or are rewarded for these additional hours with higher pay. Finally, there is the OUT_HR $\mathrm{H}_{\mathrm{t}}$ variable, which was estimated using instrumentation. This estimated coefficient is positive because output per hour is a measure of productivity, and higher earnings typically accompany increases in productivity. Thus, all of the signs make sense in the overall model.

Based on econometric testing, the overall model is strong individually and overall, takes on the correct functional form, and does not omit any variables. Therefore, many reliable conclusions can be drawn from the model and applied towards the nation's youth as a whole. The largest takeaway from the overall model is that the scarring effect exists for earnings and is delayed slightly longer than on the unemployment side of this economic phenomenon.

(ii) Analysis of Gender and Race: For the most part, the various controls used in Model 2 appear to be fairly similar across genders and races in terms of signs and statistical significance; however, where they seem to diverge again is in terms of the differences in magnitudes of the fourth lagged term of the youth unemployment rate. According to these results, females experience a slightly larger decrease in earnings than males with an increase in the corresponding youth unemployment rate, while Whites experience the highest drop in future earnings, followed by Blacks then Hispanics. It makes sense that Black and Hispanic youths would see a smaller decrease in earnings because their earnings levels are already much lower and their skills are assumed to be much less developed, so past unemployment should not change their situation as greatly as it does for Whites. That is, Blacks and Hispanics are probably going to be offered lower pay than Whites regardless of past unemployment, so the scarring effect should be less extreme. On the other hand, although 
females are estimated to feel a slightly larger drop in earnings than males, the difference is not significant. Nevertheless, this ordering of the genders makes sense because of the gender gap in pay despite the similar skill and education levels of the genders. That is, because on average females are paid less than men. If females give future employers reason to believe that they are lazy, incompetent, etc. due to past unemployment spells, thus appearing to confirm employers' generalizations "biases" about the gender, companies might offer even lower pay as a result. However, unlike in Model 1, because of the statistical significance of the $\mathrm{YUR}_{\mathrm{t}-4}$ estimated coefficients for all of the genders and races, it can be concluded that the earnings component of the scarring effect is present for all of the groups under examination, albeit to different extents.

(iii)_Main Takeaway: Despite the different levels of the scarring effect felt by each demographic group in terms of earnings, this economic phenomenon was shown to exist nationally as well as in all of the examined genders and races after the fourth lag of the youth unemployment rate. The primary implication of this finding is that previous increases in the youth unemployment rate tend to lead to decreases in future earnings across the American youth population, with slightly more delayed effects than are felt regarding future unemployment.

E. Reconciling Model 1 and Model 2: As one can see from Model 1 and Model 2, both parts of the scarring effect do exist in reality (i.e., in terms of future unemployment and earnings). Even though the models and their conclusions are similar in many aspects, there are some differences that require attention. First, is the number of lags incorporated in each of the models. Model 1 uses the first lagged term of the youth unemployment rate while Model 2 uses the fourth lagged term. As mentioned previously, this was done in order to illustrate the time in which the scarring effect relationship takes to appear on each of the unemployment and earnings sides. Because it takes longer in the $\mathrm{EARN}_{\mathrm{t}}$ model, it makes sense to include the fourth lag, but because it occurs more quickly in the $\mathrm{YUR}_{\mathrm{t}}$ model, it was not necessary to go past one lag.

Another difference between the two models is the statistical significance and conclusions that can be drawn from the female, Black, and Hispanic sub-models. While these sub-models in Model 1 produced statistically insignificant results for the aforementioned sub-models in terms of the scarring effect, they were much stronger and definitive in Model 2. Although it is not clear precisely what the effect of past unemployment is on these groups' future unemployment, it is apparent that there is a significant negative effect on their future earnings. This is an interesting finding because it illustrates general inconsistency in gender and racial comparisons, making it much harder to direct policy changes. However, given general theory, one would recommend focusing much of the new policy towards minorities because of their assumed lower levels of education, skills, training, and opportunity as well as females because of their generally worse labor market outcomes compared to males.

In all, by looking at Model 1 and Model 2 together, there is considerable evidence that the scarring effect does exist at least to some extent at a national level and for all of the genders and races examined in 
the current study. Even though these groups of youths may experience this economic phenomenon in different ways, it is still apparent that past youth unemployment has consequences for young Americans later on.

F. Comparing the Youth and Adult Unemployment Rates: In order to supplement the work that focused specifically on the youth scarring effect, the relationship between the youth unemployment rate and the adult unemployment rate was also examined. In order to do so, a Vector Error Correction (VEC) model and a regression with the adult unemployment rate as the dependent variable were run to look at the relationship between the two measures as well as to determine which age group suffers more severely from the scarring effect. These two additional set of results are presented in appendix A and B, respectively.

G. Relevance to Policymaking: This study has confirmed the existence of the scarring effect on the national level for the examined genders and races, so its results can be easily transformed into policy implications. Through the use of the recommendations described below, it is the hope of this study that the issue of high youth unemployment and its consequences, particularly those associated with the scarring effect, will be reduced.

As shown in this study, spells of unemployment in one's youth can create permanent scars, such as unemployment and lower wages in the future especially if the young person does not successfully find employment early in his or her career. Although unemployed youths are likely to experience damage to future employment prospects and the lowering of subsequent earnings, re-entry into the labor market can initiate the accumulation of human capital and potentially limit the scarring effects. Therefore, lessening the issue of youth unemployment should be of pressing concern to the government in order to limit the consequences of currently unemployed youths entering the laboring market in the future. By failing to address this issue, it is likely that the consequences of youth unemployment will continue to build, especially given the persistent lack of job opportunities and ineffective programs helping ease school-to-work transitions. The high level of unemployment amongst youths calls for targeted policies to help these workers find employment and regain their footing in the labor market. Addressing the issue of youth unemployment would hopefully minimize scarring effects while benefitting society and the economy as a whole. It is crucial however, to keep in mind the importance of preventing unemployment in the first place because the initial interruption is found to cause the largest penalty (Arulampalam, 2001).

(i) Policy Implications From Current Study: There are many policy implications that can be drawn from this study, given that many of the independent variables from Model 1 and Model 2 are in fact heavily influenced by changes in policy. Policy recommendations include actions that improve the health of the economy because of the demonstrated negative relationship between real GDP per capita and the youth unemployment rate and, positive relationship between real GDP per capita and real median weekly youth earnings. Next, due to the positive relationship between output per hour and real median weekly youth earnings, it is evident that initiatives should be created that focus on increasing the productivity of youths. 
Additionally, work should be done to boost high school graduation rates and implement other educational reforms to improve the standing of youths within the labor market. This would also be beneficial in increasing the productivity of youths. And again, as discussed previously, even though Model 1 suggests that a decrease in spending on training would help limit youth unemployment in the current time period, it would probably be more beneficial in the long-run to increase spending on training and/or make adjustments to how this money is spent. Even though it would take time for this increase in spending to filter through the system and decrease youth unemployment, it would be worth the wait because of the assumed corresponding drop in the youth unemployment rate. These ideas for policy changes extracted from Model 1 and Model 2 are likely to have a meaningful impact on the outlook on future employment and earnings for unemployed youths because of their targeting of the important issues identified in the current study.

(ii) Gender and Race Specific Policy Implications From Current Study: In addition to these targeted policy changes, attention should be focused on bettering high school graduation rates for female, Black, and White youths, improving the health of the economy for female and Hispanic youths, and increasing productivity for male, Black, and White youths. Thus policy changes must be made at both targeted and national levels to aid certain people who would benefit most from that type of action. These are just a few examples of policy implications from this study, and there are many more to be taken from the results of Model 1 and Model 2. However, the literature also offers several policy recommendations that should be taken into consideration.

(iii) School-to-Work Transitions: In addition to the policy implications that result directly from the current study, the literature also offers several options. For example, more attention needs to be paid to labor market policies and the school-to-work transition in order to reduce the risk of high youth unemployment (Choudhry et al., 2012). The school-to-work transition could be eased through expanded and improved government-sponsored training programs that provide youths with the skills necessary to succeed in their careers and that lessen the gap between the skills employees need and the skills being taught in school. Although the sign of the TRAIN $\mathrm{t}_{\mathrm{t}}$ estimated coefficient in Model 1 suggested otherwise, training programs can be beneficial in many ways; there may just be delayed effects or a need for adjustments in the approach to training. The objective of youth unemployment programs is to improve the employment possibilities for unemployed youths by helping to build their skills. Schools play a large role in this mission because it is part of their duty to generate new ways of matching training opportunities and job needs in school so as to reduce the unemployment of their students upon graduation. In fact, by promoting vocational education and training, schools can help young people move into more productive and sustainable jobs by creating the necessary preconditions for the employability of youths and better aligning educational instruction with workforce demand. Schools can also provide students with more career guidance in order to better prepare them for job searches during their school-to-work transition. This could be accomplished by incorporating career-related information and opportunities into the academic curricula; however, just solely providing students with 
general career-related training and education will not be as beneficial as providing students with information about and access to jobs that are in demand.

Job opportunities can be created for youths by providing them with the necessary tools and training required to ensure they acquire the skills and expertise needed for the working world, and youths can be further engaged through the creation of partnerships between employers and educational institutions (Coenjaerts, Ernst, Fortunny, Rei, and Pilgrim, 2009). One initiative that has been adopted by many schools across the country is working with local companies to identify where students' skills typically lack and developing complementary programs to improve upon these deficiencies. Employers can also partner with school and vocational institutions to increase youths' exposure to the working world as well as to encourage schools to adopt classes that help young people find jobs and develop relevant skills for the workplace. The educational system often times places little emphasis on building skills in their students that have practical applications for the workplace. Thus, there needs to be a better alignment of training initiatives and real work opportunities, which can be accomplished through training-to-employment programs. These programs would train youths regarding the necessary skills for specific and available jobs and also include post-training job placements. As a result, employers would be able to address their skills shortages while providing work opportunities for youths who probably would not have been able to obtain these jobs on their own.

Similarly, this system could be enhanced by better connecting job training to actual placement in a job, whereby unemployed youths are paired with corporations for training and employment. Shifting unemployed youths into subsidized employment or training would also help limit the negative consequences of youth unemployment (Hills, 1990). Paid or unpaid work experiences such as internships, apprenticeships, and job shadowing also offer promise because of the exposure of young people to new occupations and opportunities. Also, because these experiences can be structured in a low-risk way, youths can be provided with these opportunities without long-term commitments. These experiences can also be incorporated into a summer or semester-long program during a youth's ongoing education. Another option for youths is entrepreneurship or self-employment. Even though there are some barriers to unemployed youths becoming entrepreneurs, such as their shorter credit history and lack of access to business networks, entrepreneurship is another avenue for career success and unleashing the economic potential of young people. Thus, the promotion of youth entrepreneurship can positively affect the young entrepreneurs themselves while also generating employment among their peers and communities (Kabaklarli et al., 2011).

(iv) Government Policies: The federal government has made some attempts to address the issue of youth unemployment in the past. Ones that are focused primarily on preparing students for positive academic outcomes through education include the High School Graduation Initiative, Magnet Schools Assistance Program, Teacher Incentive Fund, Upward Bound, and American Graduation Initiative. In addition, there is also an apprenticeship program through the Division of Youth Services in the Department of Labor. Meanwhile, there are other federal initiatives that focus on youth empowerment, specifically for at-risk 
youth, such as the Workforce Investment Act, Serve America Act, and Urban Jobs Act (Ayres, 2013). But even though the federal government has taken part in these initiatives, high levels of youth unemployment still persist. Much of these programs' limited ability to successfully address this issue can be attributed to the disorganized coordination and diffuse spread of responsibility among different government agencies. A pressing issue such as youth unemployment requires organized and meaningful action in order to be contained.

With the Workforce Investment Act (1998), there was an attempt to consolidate workforce preparation and development programs into a unified and coordinated system. This provided a new framework to meet the needs of businesses as well as the training, education, and employment needs of job seekers who want to become more successful in their careers. This act also specified three groups of federal funding recipients: adults, dislocated workers, and youths. For youths specifically, an emphasis was placed on postsecondary educational opportunities and employment, with programs that connected academic and occupational learning. Among others, these programs also included work experience, occupational skills training, and leadership development (Bradley, 2013). Therefore, the creation of the Workforce Investment Act demonstrated the government's commitment to reducing youth unemployment and set up a framework through which future steps could be taken. However, despite the good intentions set forth by the Workforce Investment Act, these measures have not reached their potential in reducing the youth unemployment rate.

Unfortunately, Congress is taking some steps backwards from the goal of reducing youth unemployment given the recent sequestration and decisions to end programs that were proven to put young people to work. In fact, Congress has cut $\$ 1$ billion from youth jobs programs over the past decade (Ayres, 2013), and even those efforts that have been taken to reduce youth unemployment have not been as effective as they could be. Youth unemployment is an important issue and requires a great amount of attention, and the first step in this process is putting an end to funding cuts and beginning to take youth unemployment more seriously.

Another way for the government to tackle the issue of youth unemployment is to stimulate the demand for young people in the labor market through the introduction of active labor market measures. Examples include offering wage and training subsidies or tax and national insurance breaks/credits to employers (Maguire, 2013). Similarly, an emphasis could be placed on compensation-based policies because a reduction in an employer's labor cost is likely to lead to an increased demand for young workers. Alternatively, the youth sub-minimum wage could be expanded (Kaestner, 1996). Given the Fair Labor Standards Act, individuals are able to receive sub-minimum wages if they are student-learners (vocational education students), have a physical or mental disability, or are full-time students employed by retail or service businesses, agriculture, or higher educational institutions. A sub-minimum wage prevents the loss of employment opportunities for these individuals and therefore the scarring effect; however, even though a sub-minimum wage is likely to reduce these consequences, it also decreases the earnings of these youths. 
Thus, an expansion of the sub-minimum wage could work to the advantage of youths in terms of future employment and wage outcomes, but it would come at a cost to current wages.

As demonstrated through the federal government's relative inability to successfully contain the issue of youth unemployment, it is apparent that policy changes might be more effective when implemented on a state or local government basis. This way, spending could be directed more specifically and programs could better address the needs of a specific subset of youths. As shown in the current study, the population is not evenly distributed across the nation, with different genders and races requiring different types of attention. Therefore, the issue could probably be better contained through targeted initiatives rather than through broadsweeping federal policies and actions.

(v) What to Keep in Mind Going Forward: Although reducing youth unemployment is a challenging task, there are many potential solutions. Current employment policies should be used as a basis for the increased support of youths, with targeted interventions utilized when necessary. However, there are several factors that need to be considered when formulating policy recommendations. First, there needs to be an importance placed up the differentiation between "preventative" and "reintegration" strategies. While both prevention and reintegration need to be addressed, each of these solution categories require separate attention, given their different motivations. Second, even though it is critical to stimulate the demand for young workers, the quality of the jobs they occupy must be maintained. In addition to allowing young people to gain greater access to opportunities within the labor market, emphasis should be placed on improving the quality and security of jobs they are able to obtain and ensuring that young workers are receiving a living wage. Third, it is important to keep in mind the impact policy recommendations that focus on youths have on other age groups. Even though it would be beneficial to make policy changes in the interest of youths, this should not come at a cost to older workers. With an increase in the hiring of unemployed youths, this may sometimes result in older providers for families being laid off as well as other issues for different age groups. So policymakers must keep in mind potential consequences for other parts of the economy that could come with an attempt to stimulate youth employment (Maguire, 2013). Finally, it is important to recognize that unemployment is not just a supply-side phenomenon. Supply-side policies that make individuals more employable and increase work incentives should appear alongside demand-side policies to hopefully lower the youth unemployment rate. Overall, through the promotion of policies that focus on decreasing youth unemployment and take these concerns into consideration, the government will help to avoid a "lost generation" and instead foster a generation of productive workers.

As demonstrated through the results found in this study, it is evident that the scarring effect does exist, albeit in different ways for different groups of people. That is, past youth unemployment has been shown to have a positive relationship with current unemployment and a negative relationship with current youth earnings. However, the collective consequences of youth unemployment, particularly scarring effects, 
continue to challenge policymakers to develop successful and sustainable interventions. Given the several options presented throughout this study, it is apparent that there is hope for future containment of this issue.

\section{CONCLUSIONS AND POSSIBLE EXTENSIONS}

Through the estimation of the models in the current study, it has been shown that while the scarring effect does tend to result from past youth unemployment, there are also several methods through which this issue could be reduced. Even though this study was thorough in its testing and exploration of the topic, there are still additional steps that would be beneficial to take in the future to learn more about this economic phenomenon.

In terms of future extensions of this study, it would be interesting to apply both Model 1 and Model 2 to a specific state or city where youth unemployment and its scarring effect have been particularly severe. This way the policy recommendations could be targeted more specifically and have a greater impact. This would also allow for the incorporation of state minimum wages, rather than solely the federal minimum wage. According to the National Conference of State Legislatures, 29 states and Washington DC will have minimum wages above the federal minimum wage during this upcoming fiscal year, which is a trend dating back in time. NOTE: Because a large portion of the population receives a minimum wage higher than the federal minimum wage, the proposed models might not be as strong as they could be in regards to this measure.

It would also be interesting to include other models with additional races in order to compare these results to the ones already generated. By failing to examine several other races, this study is missing out on potentially beneficial findings that would lead to better policy implications. Also, the scarring effect in the adult context was only briefly examined in the current study, and it would be interesting to supplement these results with the scarring effect on adults as it should not be completely overshadowed by the youth experience. Additional possibilities include adding more lagged youth unemployment terms, incorporating variables that account for structural changes in the economy, and estimating these models as a system. In terms of using system estimation, the reason why the current study does not utilize this technique is because it was key to identify the effects of past youth unemployment on future youth unemployment and earnings individually. This could not be accomplished by estimating the two models as a system. Finally, it is also important to tie in unemployment benefits and how they interact with the current model. If youths are unemployed and unemployment benefits are available to them, many would be incentivized to remain unemployed, so this is an important factor to consider in future studies. Thus, there are many possibilities for future extensions of this work that build upon what has already been accomplished.

The current study contributes many new findings to the existing literature through an updated examination of this topic that analyzes more current data, resulting in more relevant and useful policy implications. Additionally, the findings in the current study are valuable because they offer a comprehensive 
look at youth unemployment and the various economic factors that contribute to its value. Previous studies tended to focus on one particular issue, such as the health of the economy or the minimum wage, but it is important to take many other factors into consideration because the youth unemployment rate is a complex issue. Therefore, through the incorporation of factors from throughout the economy, the current study is able to generate conclusions that provide more all-encompassing conclusions regarding the scarring effect.

As demonstrated in this study, early unemployment tends to lead to increased unemployment and lower earnings in the future. Given the particular relevance of this issue with the recent events that occurred during the Great Recession and the approaching release of graduating college seniors into the job market, the conclusions reached in this study are very important in understanding the extent to which various economic factors contribute to youth unemployment, how different aspects of the scarring effect act for different subsets of the youth population, and how policymakers can address these issues to support youths. Based on the previously discussed results, youth unemployment is indeed a dismal science because of its damaging scarring effects, but through the adoption of some of the policy recommendations outlined in the current study, progress can be made with regard to creating a better state for youths within the labor market. 


\section{BIBLIOGRAPHY}

Andreas Knabe and Steffen Ratzel, "Scarring or Scaring? The Psychological Impact of Past Unemployment and Future Unemployment Risk,” Economica, 78 (2011): 283-293.

Aris Accornero, “Recent Trends and Features in Youth Unemployment,” Labour, 3, no. 1 (1989): 127-147.

Aspen Gorry, “Minimum Wages and Youth Unemployment,” European Economic Review 64 (2013): 57-75.

Bart Cockx and Matteo Picchio, "Scarring Effects of Remaining Unemployed for Long-Term Unemployed School-Leavers,” Journal of the Royal Statistical Society 176, no. 4 (2013): 951-980.

Bureau of Economic Analysis, United States Department of Commerce, http://www.bea.gov.

Bureau of Labor Statistics, United States Department of Labor, http://www.bls.gov.

Catherine Bruno and Sandrine Cazes, "French Youth Unemployment: An Overview," Employment and Training Department International Labour Office Geneva (1998): 1-25.

Claudia Coenjaerts, Christoph Ernst, Mariangels Fortunny, Diego Rei, and Markus Pilgrim, "Youth Unemployment," Promoting Pro-Poor Growth: Employment (Organization for Economic Cooperation and Development, 2009), 119-131.

David G. Blanchflower, “Globalization and the Labor Market,” Trade Deficit Review Commission (2000): 186.

David H. Bradley, “The Workforce Investment Act and the One-Stop Delivery System,” Congressional Research Service Report for Congress (2013).

David N.F. Bell and David G. Blanchflower, "Youth Unemployment: Déjà Vu?” Institute for the Study of Labor Discussion Paper (2009): 1-54.

David Neumark and William Wascher, "Minimum Wages, Labor Market Institutions, and Youth Employment: A Cross-National Analysis,” Industrial and Labor Relations Review 57, no. 2 (2004), 223-248.

Dennis Görlich, Ignat Stepanok, and Fares Al-Hussami, "Kiel Policy Brief-Youth Unemployment in Europe and the World: Causes, Consequences, and Solutions," Kiel Institute for the World Economy, no. 59 (2013): 1-11.

Esra Kabaklarli, Perihan Hazel Er, and Abdulkadir Bulus. "Economic Determinants of Turkish Youth Unemployment Problem: Cointegration Analysis," International Conference on Applied Econometrics (2011): 267-272.

Economic Research: Federal Reserve Bank of St. Louis, Federal Reserve Economic Data, http://www.research.stlouisfed.org.

Michael J. Orszag and Dennis Snower, "Youth Unemployment and Government Policy," Journal of Population Economics 12, no. 2 (1999): 197-213.

Misbah Tanveer Choudhry, Enrico Marelli, and Marcello Signorelli, "Youth Unemployment Rate and Impact of Financial Crisis,” International Journal of Manpower (2012): 76-95.

Olga Demidova and Marcello Signorelli, Determinants of Youth Unemployment in Russian Regions, vol. 24 no. 2 of Post-Communist Economies (Taylor and Francis, 2012), 191-217. 
Paul Gregg and Emma Tominey, “The Wage Scar from Male Youth Unemployment,” Labour Economics 12, no. 4 (2005): 487-509.

Ramon Gomez-Salvador and Nadine Leiner-Killinger. "An Analysis of Youth Unemployment in the Euro Area,” European Central Bank Occasional Paper Series, no. 89 (2008): 1-43.

Richard B. Freeman and David A. Wise, eds., The Youth Labor Market Problem: Its Nature, Causes, and Consequences, (Chicago: University of Chicago Press, 1982), 1-16.

Robert Kaestner, “The Effect of Government-Mandated Benefits on Youth Employment," Industrial and Labor Relations Review 50, no. 1 (1996), 122-142.

Sarah Ayres, “The High Cost of Youth Unemployment,” Center for American Progress (2013).

Stephen M. Hills, "Race and Sex Differences in the Effects of Early Unemployment on Wages," Review of Black Political Economy 18, no. 4 (1990): 13-36.

Sue Maguire, "What Measures Can be Taken to Address the Specific Problem of Young People Who Are NEET,” Intereconomics/Review of European Economic Policy 48, no. 4 (2013): 196-201.

Trine Filges and Birthe Larsen, "The Impact of Youth Unemployment Policy: A Shift of Workers into the Skilled Labor Force,” Labour 18, no. 3 (2004): 379-414.

United States Department of Education, http://www.ed.gov.

United States Department of Labor, http://www.dol.gov.

Wiji Arulampalam, "Is Unemployment Really Scarring? Effects of Unemployment Experiences on Wages," Economic Journal 111, no. 475 (2001): F585-F606.

Wiji Arulampalam, Paul Gregg, and Mary Gregory, “Unemployment Scarring,” Economic Journal 111, no. 475 (2001): F577-F584. 


\section{APPENDIX A: VEC Model Results}

Please refer to the following figure (left panel) suggesting that there is a long-term relationship between $\mathrm{YUR}_{\mathrm{t}}$ and $\mathrm{ADULT}_{\mathrm{t}}$. Further, both YUR and ADULT are I(1) and are cointegrated, accordingly a VEC modeling was employed (right panel). As one can see, the error correction coefficients take on opposite signs, suggesting that there is a long-term equilibrium relationship between $\mathrm{YUR}_{t}$ and $\mathrm{ADULT}_{\mathrm{t}}$.

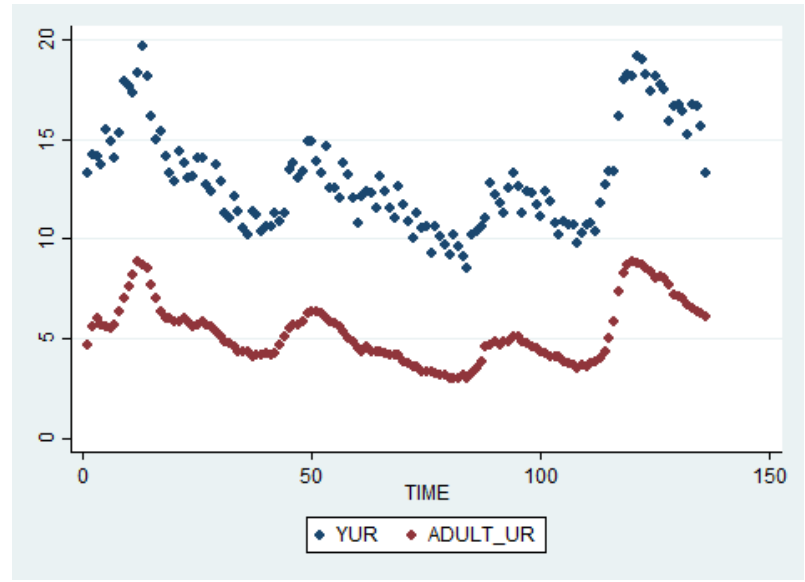

\begin{tabular}{|c|c|c|}
\hline \multicolumn{3}{|c|}{ Vector Error Correction Estimates } \\
\hline \multicolumn{3}{|c|}{$\begin{array}{l}\text { Vector Error Correction Estimates } \\
\text { Date: 01/09/15 Time: } 12: 02 \\
\text { Sample (adjusted): } 3136 \\
\text { Included observations: } 134 \text { after adjustments } \\
\text { Standard errors in ( ) \& t-statistics in [] }\end{array}$} \\
\hline Cointegrating Eq: & CointEq1 & \\
\hline YUR(-1) & 1.000000 & \\
\hline ADULT_UR(-1) & $\begin{array}{r}-1.618819 \\
(0.04814) \\
{[-33.6305]}\end{array}$ & \\
\hline C & -4.464719 & \\
\hline Error Correction: & D(YUR) & D(ADULT_UR) \\
\hline CointEq1 & $\begin{array}{r}-0.761868 \\
(0.11167) \\
{[-6.82227]}\end{array}$ & $\begin{array}{c}0.051766 \\
(0.03210) \\
{[1.61259]}\end{array}$ \\
\hline D(YUR(-1)) & $\begin{array}{l}0.200821 \\
(0.09652) \\
{[2.08063]}\end{array}$ & $\begin{array}{r}-0.010729 \\
(0.02774) \\
{[-0.38668]}\end{array}$ \\
\hline D(ADULT_UR(-1)) & $\begin{array}{r}0.797800 \\
(0.24863) \\
{[3.20874]}\end{array}$ & $\begin{array}{l}0.667878 \\
(0.07147) \\
{[9.34481]}\end{array}$ \\
\hline c & $\begin{array}{r}-0.019689 \\
(0.06973) \\
{[-0.28236]}\end{array}$ & $\begin{array}{r}-0.004059 \\
(0.02004) \\
{[-0.20250]}\end{array}$ \\
\hline $\begin{array}{l}\text { R-squared } \\
\text { Adj. R-squared } \\
\text { Sum sq. resids } \\
\text { S.E. equation } \\
\text { F-statistic } \\
\text { Log likelihood } \\
\text { Akaike AIC } \\
\text { Schwar SC } \\
\text { Mean dependent } \\
\text { S.D. dependent }\end{array}$ & $\begin{array}{r}0.365822 \\
0.351187 \\
84.58923 \\
0.806651 \\
24.99654 \\
-159.3156 \\
2.437546 \\
2.524048 \\
-0.006716 \\
1.001442\end{array}$ & $\begin{array}{l}0.466776 \\
0.454470 \\
6.989578 \\
0.231875 \\
37.93326 \\
7.741355 \\
-0.055841 \\
0.030662 \\
0.003731 \\
0.313939\end{array}$ \\
\hline $\begin{array}{l}\text { Determinant resid cova } \\
\text { Determinant resid cova } \\
\text { Log likelihood } \\
\text { Akaike information crite } \\
\text { Schwarz criterion }\end{array}$ & $\begin{array}{l}\mathrm{ce} \text { (dof adj.) } \\
\mathrm{ce}\end{array}$ & $\begin{array}{r}0.028640 \\
0.026955 \\
-138.1660 \\
2.211433 \\
2.427690\end{array}$ \\
\hline
\end{tabular}

This is an important finding because it was now confirmed that there is a relationship between the adult and youth unemployment rates; therefore, one would expect them to be affected by similar factors and react in similar ways, for the most part. But this brought about the question of how the scarring effect comes into play in this relationship.

\section{APPENDIX B: Regression with ADULT $T_{t}$ as the Dependent Variable}

A similar model to Model 1 one was used for adults in order to draw comparisons between the scarring effect for youths and adults. Many of the same independent variables used in the youth models were incorporated in the adult unemployment rate model, but TRAIN $\mathrm{t}_{\mathrm{t}}$ was excluded because it primarily affects youths and does not have much of an impact on adults. Also, $\mathrm{YUR}_{\mathrm{t}}$ was excluded from the ADULT $\mathrm{T}_{\mathrm{t}}$ model because even though the adult unemployment rate is shown to affect the youth unemployment rate, there is less evidence for the opposite direction. This is because youths compose a small portion of the labor force when compared to adults and do not occupy as many important positions within the labor market. 
Additionally, this study only estimated a model with the adult unemployment rate as the dependent variable and not one with adult earnings because this was not the main focus of this study, and given the supplementary nature of this regression, it was not explored as far in depth. Also, this model was only run on the national level without gender or race segmentation, which led to more general conclusions. Again, this was done for simplification because the ADULT $t$ model was not the main focus of the current study. Finally, Newey West standard errors were used to generate more reliable measures of statistical significance.

Table 5: Regression Results (Model 3- ADULT $T_{t}$ as dependent variable)

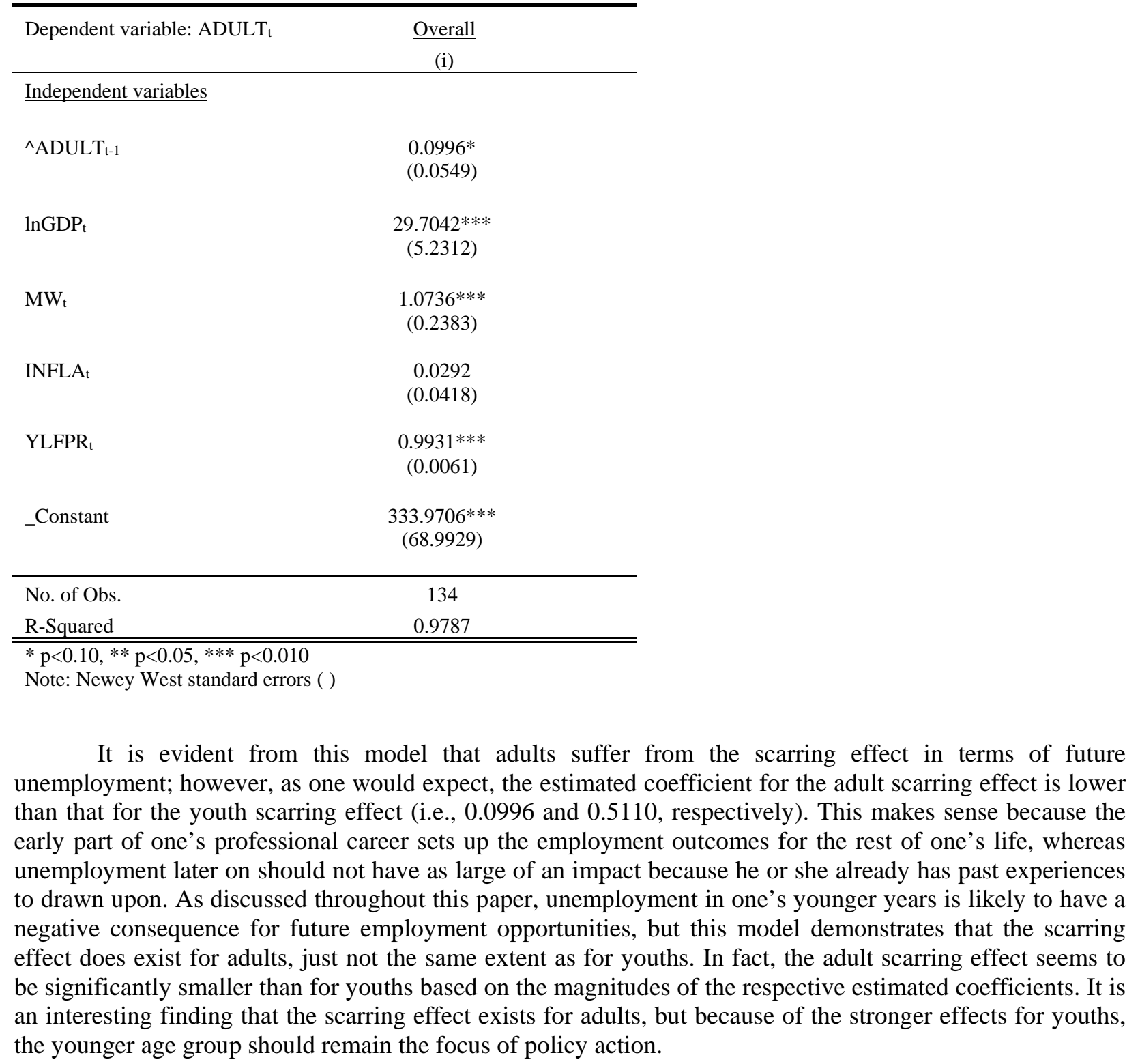

